\title{
Chiclero's ulcer: An unusual presentation of Leishmania tropica in Syria
}

\author{
Alexey Youssef, Samar Yaseer ${ }^{1}$, Rim Harfouch², Maya Marouf, Foz Hasan²
}

Faculty of Medicine, Tishreen University, Lattakia, 'Department of Dermatology, Faculty of Medicine, Tishreen University, Lattakia, ${ }^{2}$ Department of Microbiology and Biochemistry, Al Andalus Private University, Tartous, Syria

\begin{tabular}{|c|}
\hline Access this article online \\
\hline Website: www.avicennajmed.com \\
\hline DOI: 10.4103/ajm.AJM_145_17 \\
\hline Quick Response Code: \\
\hline \\
\hline
\end{tabular}

\begin{abstract}
Cutaneous leishmaniasis $(C L)$ has been an endemic disease in Syria for decades. The first reports of $C L$ from the Syrian city Aleppo date back to the $17^{\text {th }}$ century. The recent crisis has further empowered the spread of this infection not only in Syria, but also in the neighboring countries. Here, we describe a case of a 67-year-old patient with a 6-month, nonhealing ulcerative lesion of the left auricle. It was initially diagnosed as either a squamous or a basal cell carcinoma. However, the biopsy revealed an unexpected finding of Leishmania amastigotes in the histiocytes. Consequently, CL of the auricle, chiclero's ulcer, was diagnosed. Polymerase chain reaction, in turn, revealed Leishmania tropica to be the causing factor; a rather rare one for chiclero's ulcer. The lesion completely resolved after a 3-week glucantime regimen, without any recurrence after an 8-month follow-up.
\end{abstract}

Key words: Chiclero's ulcer, cutaneous leishmaniasis, Leishmania tropica

\section{INTRODUCTION}

Cutaneous leishmaniasis (CL) is an infectious disease spread by the female sand fly (vector). In general, it affects the body parts that are mostly exposed to the vector bites, such as the face and forearms. However, auricular involvement is a rather rare finding known as chiclero's ulcer, especially in Mexico.

\section{CASE REPORT}

We present the case of a 67-year-old man residing in Latakia city, with a history of hypertension and prostatic hyperplasia. He presented to the dermatology clinic with a lesion on his left auricle. On examination, the whole auricle was erythematous and edematous, with multiple ulcerations and a $5-\mathrm{mm}$ protruding mass on the concha [Figure 1]. There were accompanying crusts and a discharge, but no pain, pruritus, or fever. In addition, no regional lymph node enlargement was noted. The patient reported that the lesion started as a small papule 6 months earlier, without any response to topical or systemic antibiotics.

Address for correspondence: Maya Marouf,

Faculty of Medicine, Tishreen University, Lattakia, Syria.

E-mail: maroufmaya96@gmail.com
At presentation, the specialists at our institution biopsied the patient's lesion. The biopsy revealed an unanticipated finding. It showed dermis-located granulomatous foci composed of diffuse lymphocytic inflammatory infiltrates and histiocytes that contain small oval parasitic organisms. The epithelium is ulcerated above the lesion. Confirming the diagnosis of leishmaniasis, Giemsa stain disclosed Leishmania amastigotes inside the histiocytes [Figure 2]. Polymerase chain reaction test revealed that Leishmania tropica was the causing factor. The patient's chest X-ray was normal and his laboratory results are presented in Table 1. Considering the cardiac side effects of systemic leishmaniasis therapy with meglumine antimoniate, a cardiology consultation was obtained. The latter showed no abnormalities; thereby the patient was put on a regimen of $20 \mathrm{mg} / \mathrm{kg} /$ day meglumine antimoniate (Glucantime $e^{\circ}$ intramuscularly. Later on, an elevation in C-reactive protein $(67 \mathrm{mg} / \mathrm{dl})$, in addition

This is an open access journal, and articles are distributed under the terms of the Creative Commons Attribution-NonCommercial-ShareAlike 4.0 License, which allows others to remix, tweak, and build upon the work non-commercially, as long as appropriate credit is given and the new creations are licensed under the identical terms.

For reprints contact: reprints@medknow.com

Cite this article as: Youssef A, Yaseer S, Harfouch R, Marouf M, Hasan F. Chiclero's ulcer: An unusual presentation of Leishmania tropica in Syria. Avicenna J Med 2018;8:117-9. 


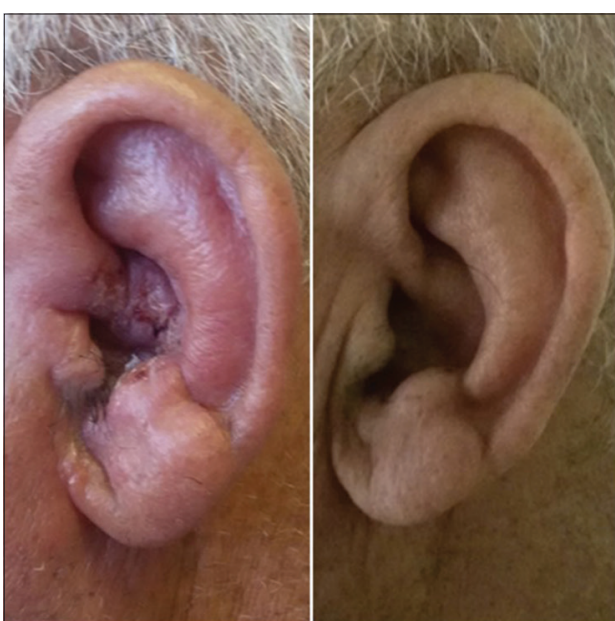

Figure 1: The lesion before therapy and after 8 months

\begin{tabular}{|c|c|c|}
\hline The test & Value & Reference range \\
\hline Hematocrit (\%) & 41.5 & $35-45$ \\
\hline \multirow[t]{2}{*}{ Hemoglobin (g/dl) } & 14.3 & Male: I3-18 \\
\hline & & Female: $12-16$ \\
\hline White cell count $\left(/ \mathrm{mm}^{3}\right)$ & 7600 & $4000-10,000$ \\
\hline \multicolumn{3}{|l|}{ Differential count $(\%)$} \\
\hline Lymphocytes & 33.1 & $|9-5|$ \\
\hline Granulocytes & 60.4 & $35-75$ \\
\hline Platelet count $\left(/ \mathrm{mm}^{3}\right)$ & 233,000 & $150,000-450,000$ \\
\hline Red cell count $\left(/ \mathrm{mm}^{3}\right)$ & $5,060,000$ & $\begin{array}{l}\text { Male: } 4.5-6.2 \text { millions } \\
\text { Female: } 4-5.4 \text { millions }\end{array}$ \\
\hline Mean corpuscular volume (fl) & 82 & $78-98$ \\
\hline Mean corpuscular hemoglobin (pg) & 28.2 & $27-32$ \\
\hline $\begin{array}{l}\text { Mean corpuscular hemoglobin } \\
\text { concentration }(\mathrm{g} / \mathrm{dl})\end{array}$ & 34.4 & $33-36$ \\
\hline Creatinine $(\mathrm{mg} / \mathrm{dl})$ & 1.23 & $0.5-1.2$ \\
\hline Urea $(\mathrm{mg} / \mathrm{dl})$ & 23.5 & $5-45$ \\
\hline CRP (mg/dl) & 67 & $0.5-5$ \\
\hline $\operatorname{ALT}(\mathrm{U} / \mathrm{L})$ & 29.8 & $5-40$ \\
\hline Alkaline phosphatase (mg/dl) & 73 & $40-125$ \\
\hline Amylase $(\mathrm{mg} / \mathrm{dl})$ & 77 & $<100$ \\
\hline Total bilirubin (mg/dl) & 0.5 & $0.18-0.94$ \\
\hline Direct bilirubin (mg/dl) & 0.04 & $0-0.3$ \\
\hline \multirow{2}{*}{$\begin{array}{l}\text { Erythrocyte sedimentation } \\
\text { rate }(\mathrm{mm} / \mathrm{h})\end{array}$} & 15 & Male: $0-10$ \\
\hline & & Female: 3-15 \\
\hline Glucose (mg/dl) & 89 & $70-110$ \\
\hline Sodium (mmol/L) & 142 & $135-\mid 45$ \\
\hline Potassium (mmol/L) & 4.2 & $3-5$ \\
\hline \multirow[t]{2}{*}{ Gamma-glutamyl transferase (U/L) } & 23 & Male: $10-55$ \\
\hline & & Female: 5-35 \\
\hline Cholesterol (mg/dl) & 123 & $<200$ \\
\hline Triglycerides (mg/dl) & 122 & $53-150$ \\
\hline
\end{tabular}

to auricular erythema and edema, led to the diagnosis of perichondritis. In this vein, the patient was given levofloxacin intravenously. During the treatment course, the liver function tests, amylase levels, and electrocardiography of the patient were monitored continuously, with no significant changes. The treatment was discontinued after 3 weeks and the patient was discharged from the hospital with noticeable improvement. Complete resolution

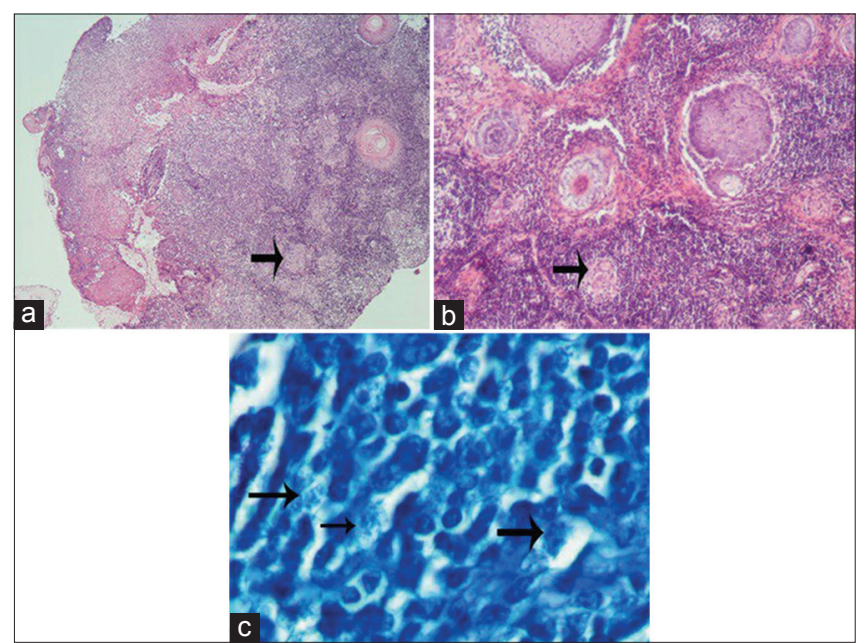

Figure 2: (a) Histopathology of the lesion. The arrow points to the granulomatous foci $(\mathrm{H}$ and $\mathrm{E}, 4 \times 10)$. (b) The arrow points to the multinucleated giant cells in the granuloma ( $\mathrm{H}$ and $\mathrm{E}, 10 \times 10)$. (c) The arrows point to the widespread Leishmania amastigotes in the histiocytes (Giemsa, 100×10)

was achieved without any recurrence after an 8-month follow-up [Figure 1].

\section{DISCUSSION}

Leishmaniasis is a major public health concern in the eastern Mediterranean region, and it is endemic in 16 of its 23 countries. Syria is a hot spot of leishmaniasis, where Aleppo is one of the most prominent CL-endemic areas in the world (12,000 new cases are reported each year), and one of the oldest as the first reports of leishmaniasis in Aleppo date back to the $17^{\text {th }}$ century. ${ }^{[1,2]}$

Since the 1970s, the number of CL cases in Syria has been growing on a steady basis. This can be attributed to the recent immense urbanization and population growth. However, this growth cannot be attributed to the recent surge of CL. In 2011 and 2012 alone, over 100,000 cases were reported. These astonishing numbers can be explained by the recent turmoil that resulted in massive population displacement, health-care infrastructure damage, and cessation of vector control programs. ${ }^{[3]}$ The most reported species causing CL in Syria were L. tropica followed by Leishmania major. Accounting for $90 \%$ of the cases, $L$. tropica is most prevalent in urban areas, especially in central provinces of Syria. In contrast, L. major accounts for $10 \%$ and is most prevalent in rural areas. Leishmania infantum accounts for the vast majority of visceral leishmaniasis cases. ${ }^{[3]}$

Biting in the night and morning times, the sand fly female, a $3.5-\mathrm{mm}$ long vector, feasts on the blood required for the development of egg batches. Most infections occur in the summer time, which is compatible with our case as it occurred in the month of July. Eight species of sand flies, 
of which seven belong to the Phlebotomus genus and one to the Sergentomyia genus, were identified in Syria during 2015 and the most predominant were Phlebotomus sergenti and Phlebotomus papatasi. ${ }^{[4]}$

In contrast to Mexico, auricular CL is rarely found in the Mediterranean region. In Mexico, it is called chiclero's ulcer, where it most commonly affects lumberjacks. Its name is derived from "Chilce," which is a substance collected by the lumberjacks to create rubber. Leishmania mexicana accounts for the vast majority of the cases there. Other types include Leishmania braziliensis and L. infantum. ${ }^{[5]}$ Interestingly, the causing factor in our case was $L$. tropica. This might imply that the causing type depends on the country and its specific leishmaniasis epidemiology. To our knowledge, only one report in the literature described L. tropica as a causing factor of chiclero's ulcer. ${ }^{[6]}$

Auricular involvement constitutes the vast majority of ear infections, since it is the area most exposed to vector bites. It may manifest as an erythematous-edematous lesion, or an ulcer. ${ }^{[5]}$ Chiclero's ulcer sometimes proves to be a mimicking disease with some complications. In certain reports, it mimicked angiolymphoid hyperplasia with eosinophilia, while in others, it mimicked carcinoma. ${ }^{[7,8]}$ Sometimes, complications might occur such as bacterial perichondritis as seen in our case. ${ }^{[0]}$

The Syrian crisis displaced over 6.5 million people, a number that is only compared to the World War 2 refugee crisis. ${ }^{[10,11]}$ Severely damaging $57 \%$ of the public hospitals, this insidious war drove $37 \%$ of the public hospitals out of service and reduced the portion of the locally produced drugs from $90 \%$ to a mere $10 \%{ }^{[11]}$ War and infectious diseases have always been intimate bedfellows. The deterioration of the health-care system along with the cessation of vector control programs and crowding created fertile ground for leishmaniasis outbreaks. These outbreaks proved to be international rather than localized. The unfortunate circumstances of refugee camps such as malnutrition, poor sanitation, and lack of health care crafted the perfect environment for leishmaniasis. The results of the aforementioned factors were the numerous outbreaks that have been recorded in the neighboring countries such as Turkey and Lebanon..$^{[1,10]}$ In addition to the surge of leishmaniasis, measles, and poliomyelitis, there are growing concerns about the spread of vector-borne diseases such as malaria and dengue fever. As Sharara and Kanj stated, this should be an international wake-up call that warrants the international community to excerpt more efforts and resources to combat the problem. ${ }^{[1]}$

Our case is, to our knowledge, the second to describe L. tropica as a causing factor of chiclero's ulcer. Since L. mexicana, L. braziliensis, or L. infantum are the usual causing species, our finding might implicate that the causing species varies depending on the local leishmaniasis epidemiological characteristics. (The most common CL species in Syria is L. tropica.)

\section{Declaration of patient consent}

The authors certify that they have obtained all appropriate patient consent forms. In the form the patient(s) has/have given his/her/their consent for his/her/their images and other clinical information to be reported in the journal. The patients understand that their names and initials will not be published and due efforts will be made to conceal their identity, but anonymity cannot be guaranteed.

\section{Financial support and sponsorship}

Nil.

\section{Conflicts of interest}

There are no conflicts of interest.

\section{REFERENCES}

1. Saroufim M, Charafeddine K, Issa G, Khalifeh H, Habib RH, Berry A, et al. Ongoing epidemic of cutaneous leishmaniasis among Syrian refugees, Lebanon. Emerg Infect Dis 2014;20:1712-5.

2. Douba M, Mowakeh A, Wali A. Current status of cutaneous leishmaniasis in Aleppo, Syrian Arab republic. Bull World Health Organ 1997;75:253-9.

3. Haddad N, Saliba H, Altawil A, Villinsky J, Al-Nahhas S. Cutaneous leishmaniasis in the central provinces of Hama and Idlib in Syria: Vector identification and parasite typing. Parasit Vectors 2015;8:524.

4. Salam N, Al-Shaqha WM, Azzi A. Leishmaniasis in the middle east: Incidence and epidemiology. PLoS Negl Trop Dis 2014;8:e3208.

5. Vaira F, Nazzaro G, Pesapane F, Veraldi S. 'Dumbo' ear. Clin Exp Dermatol 2014;39:667-8.

6. Quijano-Pitman F. Identification of Leishmania tropica mexicana as the etiologic agent of chiclero's ulcer. Gac Med Mex 1999;135:331.

7. Tarkan Ö, Çetık F, Uzun S. Auricular cutaneous leishmaniasis mimicking neoplastic disease. J Laryngol Otol 2012;126:821-4.

8. Sabri A, Khatib L, Kanj-Sharara S, Husseini ST, Nuwayri-Salti N, Semaan R, et al. Leishmaniasis of the auricle mimicking carcinoma. Am J Otolaryngol 2009;30:285-7.

9. Calzada-Hernández J, Molina-Giraldo P, Wienberg Ludwig P, Noguera-Julian A. Cutaneous leishmaniasis complicated with pseudomonas perichondritis. An Pediatr (Barc) 2014;80:327-8.

10. Al-Salem WS, Pigott DM, Subramaniam K, Haines LR, Kelly-Hope L, Molyneux DH, et al. Cutaneous leishmaniasis and conflict in Syria. Emerg Infect Dis 2016;22:931-3.

11. Sharara SL, Kanj SS. War and infectious diseases: Challenges of the Syrian civil war. PLoS Pathog 2014;10:e1004438. 